\title{
GREEN MODIFIKASI NANOPARTIKEL AU TERHADAP PERMUKAAN BENTONIT TERPILAR CU SEBAGAI DEGRADASI ZAT WARNA REMAZOL BRILLIANT BLUE R (RBBR)
}

\author{
Indra Gunawan ${ }^{1}$, Miftah Fauziah², Yoki Yulizar², dan Sudirman \\ ${ }^{1}$ Pusat Sains dan Teknologi Bahan Maju, BATAN \\ Kawasan Puspiptek Tangerang Selatan 15314 \\ ${ }^{2}$ Departemen Kimia-FMIPA-Universitas Indonesia \\ Kampus Baru UI, Depok 16424 \\ Email : yokiy@ui.ac.id
}

Received : 7 Nopember 2018; revised : 17 Januari 2019; accepted : 21 Agustus 2019

\begin{abstract}
ABSTRAK
GREEN MODIFIKASI NANOPARTIKEL Au TERHADAP PERMUKAAN BENTONIT TERPILAR Cu SEBAGAI DEGRADASI ZAT WARNA REMAZOL BRILLIANT BLUE R (RBBR). Telah dilakukan sintesis bentonit terpilarisasi $\mathrm{Cu}$ dan diimmobilisasi nanopartikel $\mathrm{Au}$ sebagai katalis degradasi termal $R B B R$ (Remazol Brilliant Blue $R$ ) menggunakan $\mathrm{H}_{2} \mathrm{O}_{2}$. Karakterisasi Na-bentonit, bentonit terpilarisasi $\mathrm{Cu}$ dan immobilisasi naopartikel $\mathrm{Au}$ di dalam Cu-bentonit dilakukan dengan menggunakan peralatan-peralatan FTIR, XRD dan SEM-EDS. Dalam kategori pewarna secara keseluruhan, $R B B R$ adalah pewarna antrakuinon yang digunakan pada industri tekstil. Ini adalah pewarna berbahaya dan dapat merusak kehidupan akuatik dan juga kehidupan vegetatif jika air yang terkontaminasi digunakan untuk irigasi. Karakterisasi degradasi dengan menggunakan spektrofotometer UV-Vis menunjukkan pada jumlah katalis $4 \mathrm{mg}$ Cu-bentonit-Au mampu mempercepat reaksi degradasi termal $R B B R$ pada konsentrasi $1,56 \times 10^{-5} \mathrm{M}$, dengan persentase dye removal mencapai $98,18 \%$. Waktu reaksi dan suhu reaksi optimum adalah 10 menit dan $98{ }^{\circ} \mathrm{C}$, sementara konsentrasi optimum $\mathrm{H}_{2} \mathrm{O}_{2}$ untuk degradasi $R B B R$ adalah $4,62 \times 10^{-1} \mathrm{M}$.
\end{abstract}

Kata kunci: Bentonit, Immobilisasi, Partikel nanopartikel Au, Degradasi $R B B R$

\begin{abstract}
GREEN MODIFICATION OF AU NANOPARTICLES ON SURFACE OF BENTONITE CU PILLARED AS A COLOR DEGRADATION OF REMAZOL BRILLIANT BLUE R (RBBR). A synthesis of branched-bentonite Cu and immobilized Au nanoparticles as $\mathrm{RBBR}$ (Remazol Brilliant Blue R) thermal degradation catalyst using $\mathrm{H}_{2} \mathrm{O}_{2}$ was performed. Characterization of Na-bentonite, $\mathrm{Cu}$-latched bentonite and immobilization of Au nanoparticles in Cu-bentonite were performed using FTIR, XRD and SEM-EDS devices. In the overall dye category, RBBR is an anthraquinone dye used in the textile industry. These are harmful dyes and can damage aquatic life as well as vegetative life if contaminated water is used for irrigation. Characterization of degradation using UV-Vis

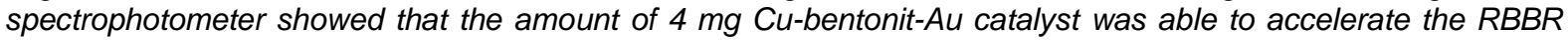
thermal degradation reaction at 1.56×10-5 M concentration, with $98.18 \%$ dye removal percentage. The reaction time and optimum reaction temperature is 10 minutes and $98{ }^{\circ} \mathrm{C}$, while the optimum concentration of $\mathrm{H}_{2} \mathrm{O}_{2}$ for degrading $R B B R$ is $4.62 \times 10-1 \mathrm{M}$.
\end{abstract}

Keywords : Bentonite, Immobilization, Nanoparticle Au, RBBR degradation

\section{PENDAHULUAN}

Bentonit adalah jenis tanah liat yang dihasilkan dari perubahan abu vulkanik, terutama terdiri dari mineral smektit, biasanya montmorilonit (Boylu et al. 2010). Tanah liat telah digunakan sebagai adsorben, penukar ion dan katalis di berbagai bidang industri karena kompatibilitas lingkungannya, biaya rendah, kesederhanaan operasi, dan ketersediaannya (Caglar et al. 2015). Bergantung pada sifat asalnya, bentonit, selain smektit, mengandung berbagai mineral. Mineral-mineral ini termasuk didalamnya kuarsa, feldspar, kalsit, opal crystobalite / trydimite (Opal-CT), illite dan mika. Kehadiran mineral semacam itu tergantung dari 
aplikasinya bisa berdampak pada nilai industri (Boylu et al. 2010). Lempung berpilar adalah bahan zeolit dua dimensi, yang disiapkan dengan menukar kation lempung terkompensasi muatan negatif dengan kation anorganik yang dibentuk oleh hidrolisis dari garam metalik (Zhirong, Uddin, dan Zhanxue 2011).

Bentonit merupakan sumber daya mineral yang melimpah terdapat di Indonesia. Mineral bentonit memiliki diameter kurang dari $2 \mu \mathrm{m}$ yang terdiri dari berbagai macam mineral phyllosilicate yang mengandung silika, aluminium oksida dan hidrosida yang dapat mengikat air. Bentonit memiliki struktur 3 layer yang terdiri dari 2 layer silika tetrahedron dan satu layer sentral oktahedral. Cadangan bentonit di Indonesia mencapai \pm 380 juta ton dan merupakan asset potensial (Syuhada et al. 2009). Bentonit dimurnikan dengan menghilangkan mineral yang terkait, atau diolah dengan asam dan pemutihan yang diaktivasi dengan asam, atau diolah dengan organik untuk menghasilkan organo-bentonit. Di industri, bentonit umumnya diklasifikasikan sebagai jenis sodium ( $\mathrm{Na}$ ), kalsium ( $\mathrm{Ca}$ ) atau campuran (Na$\mathrm{Ca}$ ), bergantung pada penukar ion yang dominan (Boylu et al. 2010). Natrium bentonit mengandung relatif lebih banyak ion $\mathrm{Na}^{+}$ dibandingkan ion $\mathrm{Ca}^{2+}$ dan $\mathrm{Mg}^{2+}$. Bentonit ini dapat mengembang hingga 8-15 kali apabila dicelupkan ke dalam air dan tetap terdispersi beberapa waktu di dalam air. Sementara kalsium bentonit mengandung lebih banyak ion $\mathrm{Ca}^{2+}$ dan $\mathrm{Mg}^{2+}$. Bentonit kalsium kurang menyerap air, akan tetapi secara alamiah, mempunyai sifat mengadsorpsi yang baik dan tetap terdispersi dalam air (Salim 2012).

Polusi lingkungan semakin menjadi perhatian publik saat ini. Terutama, dekontaminasi air dan udara yang tercemar dengan fotokatalisis telah menarik banyak perhatian untuk efisiensi dan secara ekonomi menjanjikan. Fotokatalisis semikonduktor, sebagai salah satu proses fisikokimia, dipelajari secara ekstensif untuk memecahkan masalah lingkungan yang ada (Xia et al. 2007). Pewarna sintetis dapat ditemukan di air limbah dari berbagai macam industri seperti kertas, kulit, plastik dan tekstil. Air limbah dibuang ke sungai dan aliran alami dari industri yang menggunakan pewarna menimbulkan masalah lingkungan. Bahkan sejumlah kecil pewarna dapat mewarnai badan air yang sangat besar, yang mempengaruhi nilai estetika dan mengurangi penetrasi cahaya yang dibutuhkan untuk fotosintesis. Selanjutnya, banyak pewarna bersifat toksik atau karsinogenik. Oleh karena itu, penghilangan zat warna dari limbah cair dianggap penting. Banyak pendekatan telah dikembangkan untuk dekontaminasi air, misalnya : presipitasi, elektrodialisis, adsorpsi, filtrasi, pembekuan, oksidasi dan pemisahan membran. Namun, adsorpsi dikenal sebagai salah satu teknik yang paling efektif untuk menghilangkan pewarna dalam air (Caglar et al. 2015). Karbon aktif telah dikenal sebagai adsorben karena kapasitas penyerapannya yang besar untuk pewarna. Namun, biaya tinggi membuat pencarian adsorben berbiaya rendah seperti fly ash, dan zeolit alami banyak diteliti untuk pengolahan air limbah. Beberapa bentonit modifikasi juga dilaporkan tidak mahal dan efektif dalam dekontaminasi air (Caglar et al. 2015).

Dalam kategori pewarna secara keseluruhan, Remazol Brilliant Blue $R(R B B R)$ adalah pewarna antrakuinon yang digunakan pada industri tekstil. Ini adalah pewarna berbahaya dan dapat merusak kehidupan akuatik dan juga kehidupan vegetatif jika air yang terkontaminasi digunakan untuk irigasi. Beberapa tahun terakhir telah melihat pendekatan biologis untuk memecahkan masalah ini. Penggunaan mikroorganisme untuk menurunkannya telah melihat hasil yang lebih cepat dan lebih baik daripada metode kimia. Dengan demikian, pengolahan limbah yang mengandung senyawa tersebut penting untuk perlindungan perairan dan lingkungan pada umumnya (Sari, Tachibana, dan Muryanto 2012).

Bentonit dapat digunakan sebagai penyangga katalis, sedangkan bentonit yang dimodifikasi dapat digunakan sebagai katalis. Bentonit alam kurang efektif dalam penggunaannya karena pengotor, maka perlu dilakukan pilarisasi agar kinerjanya optimal. Pilarisasi bentonit dilakukan dengan menggunakan logam, oksida logam, senyawa organik maupun anorganik. Selain dapat terpilar bentonit terpilar $\mathrm{Cu}$ dapat diimmobilisasi dengan nanopartikel Au kedalam pori Cu-bentonit terbentuk. Nano partikel logam mulia banyak dipelajari adalah $\mathrm{Au}$ karena stabil, dan aplikasinya yang luas seperti optik non linier, elektronik, sensor, katalis, dan farmaka (Rastogi et al. 2016), tetapi kelemahan nano partikel Au ini adalah harganya mahal. Karya terbaru Han et al. , menyajikan emas sebagai katalis aktif dalam proses oksidasi peroksida basah, menunjukkan stabilitas unggul emas-hidroksiapatit di atas katalis Fe / ZSM-5 dalam pengolahan air limbah berpolusi rendah (yaitu 0,1 g / L kontaminan organik seperti fenol) (Quintanilla et al. 2012). Kemudian, Quintanilla et al., menunjukkan penggunaan katalis emas juga untuk air limbah dengan muatan sedang (1-5 g / L phenol).

Saat ini, perhatian yang besar ditujukan untuk pengembangan bahan struktur nano baru untuk konstruksi platform penginderaan elektrokimia (ESPS) karena mereka menunjukkan sifat katalitik yang diakui dengan baik. Bahan berstruktur nano baru ini dapat bersumber dari unsur-unsur yang berbeda 
seperti sebagai polimer, bahan berbasis karbon, silika, lempung, dll. Di antara bahan ini, tanah liat banyak digunakan untuk pengembangan bahan berstruktur nano karena harganya murah, tidak berbahaya, mudah didapat dan sangat menjanjikan untuk disain dan persiapan bahan elektrokatalis termodifikasi secara biologis. Sejumlah besar situs pertukaran ion yang tersedia di tanah liat juga bermanfaat untuk penggabungan spesies elektroaktif dan nanopartikel (NP). Penggunaan tanah liat untuk modifikasi permukaan elektroda sudah mapan dan elektroda yang dimodifikasi tanah liat (CME) terus mendapat perhatian besar untuk pengembangan sensor dan biosensor (Shah et al. 2013).

Agen pemilar yang sangat umum digunakan adalah oksida-oksida logam. Bentonit yang terpilarisasi dengan logam polioksida dapat digunakan untuk mengoksidasi senyawa lain karena adanya kelebihan atom oksigen yang terpilar pada bentonit. Logam memiliki kemampuan daya katalitik yang baik. Logam banyak digunakan sebagai bahan katalis karena ketersediaan di alam yang melimpah, murah serta waktu hidupnya lama walaupun aktivitasnya rendah dibandingkan logam mulia (Rastogi et al. 2016). Dalam ilmu kimia, sintesis logam transisi dan nanopartikel oksida logam adalah bidang penelitian yang berkembang. Ketika partikel logam berkurang ukurannya, sifat-sifat sebagian besar partikel menghilang untuk digantikan dengan quantum dot mengikuti aturan mekanika kuantum. Dengan demikian dapat dengan mudah dipahami bahwa kimia nanopartikel logam berbeda dari bahan massal. Karena dengan pengurangan ukuran luas permukaan yang tinggi terhadap rasio volume menyebabkan peningkatan aktivitas katalitik (Shah 2011). Di antara berbagai nanopartikel logam, tembaga $(\mathrm{Cu})$ dan nanopartikel tembaga oksida $\left(\mathrm{Cu}_{2} \mathrm{O}\right)$ telah menarik perhatian karena tembaga adalah salah satu bahan yang paling penting dalam teknologi modern dan sudah tersedia (Shah 2011). Pilarisasi bentonit menggunakan $\mathrm{Cu}$ sebagai fotokalisis untuk mendegradasi zat warna Rhodamin B telah dilakukan peneliti lain (Nurdani 2012).

Dalam penelitian ini dilakukan modifikasi bentonit alam melalui penyeragaman anion $\mathrm{Na}^{+}$ dilanjutkan pilarisasi dengan logam $\mathrm{Cu}$. Modifikasi selanjutnya adalah bentonit terpilar $\mathrm{Cu}$ diimmobilisasi dengan nanopartikel $\mathrm{Au}$ kedalam pori-porinya. Bentonit termodifikasi dihipotesiskan dapat berfungsi sebagai katalis termal degradasi RBBR. Nanopartikel Au digunakan sebagai katalis karena memiliki luas permukaan yang tinggi terhadap rasio volume, dan sifat elektronik serta permukaan yang khas. Nanopartikel Au dipilih karena memiliki sifat stabil dan aplikasi yang potensial di berbagai bidang, seperti optik non linear, elektronik, sensor, katalisator, biologi dan farmaka.

\section{BAHAN DAN METODE}

\section{Bahan}

Bahan yang digunakan adalah bentonit alam (daerah Pasir Kuda, Cigudeg, Bogor). $\mathrm{Cu}\left(\mathrm{NO}_{3}\right)_{2} \cdot 3 \mathrm{H}_{2} \mathrm{O}$ (Merck, pa), $\mathrm{H}_{2} \mathrm{O}_{2}$ (Merck, pa), $\mathrm{NaOH}$ (Merck, pa), $\mathrm{HCl}$ (Merck, pa), $\mathrm{NaCl}$ (Merck, pa), $\mathrm{NaBH}_{4}$ (Merck, pa), Au batangan (PT Antam) dan bubuk Rhemazol Brilliant Blue $R$ (PT Dystar Indonesia). Larutan $\mathrm{HAuCl}_{4}$ dibuat dengan cara 0,35 g Au dilarutkan di dalam akuaregia dan dipanaskan pada $120^{\circ} \mathrm{C}$.

\section{Metode}

Penyeragaman bentonit dilakukan dengan terlebih dahulu melakukan fraksinasi bentonit. Fraksinasi bentonit dilakukan dengan memasukkan $100 \mathrm{~g}$ bentonit kedalam akuades $2000 \mathrm{~mL}$. Larutan diaduk menggunakan stirrer selama 30 menit dan didiamkan selama 5 menit. Endapan dipisahkan secara dekantasi, endapan diperoleh sebagai fraksi satu (F1). Supernatan diendapkan lagi selama 30 menit, diperoleh fraksi dua (F2). F1 dan F2 dikeringkan di dalam oven pada suhu $110{ }^{\circ} \mathrm{C}$ selama 3 jam dan disaring dengan ukuran 200 mesh. Penyeragaman kation dilakukan dengan cara $50 \mathrm{~g}$ bentonit $\mathrm{F} 2$ disuspensikan ke dalam 2x500 mL NaCl $1 \mathrm{M}$ diaduk selama 2x24 jam pada suhu $70{ }^{\circ} \mathrm{C}$ dan dipanaskan lagi selama 12 jam. Endapan dikeringkan di dalam oven pada suhu $110{ }^{\circ} \mathrm{C}$ selama 3 jam dan disaring dengan ukuran 200 mesh. Kemudian dilanjutkan dengan sintesis Cu-bentonit dengan cara membuat larutan pemilar 9,6 $\mathrm{g} \mathrm{Cu}\left(\mathrm{NO}_{3}\right)_{2}$ dan $3,6 \mathrm{~g} \mathrm{NaOH}$ didalam $200 \mathrm{~mL}$ aquades terlebih dahulu. Larutan pemilar secara perlahan ditambahkan kedalam $500 \mathrm{~mL}$ suspensi bentonit 1:25 (w/v) dengan pengadukan selama 12 jam, diikuti filtrasi dan pencucian. Sampel dikeringkan didalam oven pada suhu $110{ }^{\circ} \mathrm{C}$ dan dikalsinasi pada $450{ }^{\circ} \mathrm{C}$ selama 4 jam. Berikutnya adalah membuat $\mathrm{Cu}$-bentonit immobilisasi nanopartikel $\mathrm{Au}$, dengan cara mencampur dan mengaduk $\mathrm{HAuCl}_{4} 1 \times 10^{-4} \mathrm{M}$ selama 1 jam dan ditambahkan $7,5 \mathrm{~mL} \quad \mathrm{NaBH}_{4} \quad 0,03 \mathrm{M}$. Pengadukan terus dilakukan selama 3 jam dan dipanaskan lagi selama 24 jam kemudian dipisahkan. Padatan dikeringkan didalam oven pada suhu $105{ }^{\circ} \mathrm{C}$ selama 3 jam.

\section{Karakterisasi}

Fourrier Transform Infra Red (FTIR) untuk menentukan serapan cahaya molekul yang bergantung struktur elektronik dari molekul tersebut. Alat FTIR yang digunakan adalah TENSOR 27. $X$-ray Diffractometer $(X R D)$ untuk menentukan struktur kristal bahan yang diukur, $X R D$ yang digunakan bermerk SHIMADZU XD 
610 pada tegangan operasi $20 \mathrm{kV}$ dan $30 \mathrm{~mA}$, menggunakan target CuK $\alpha$ dengan $\lambda=1,54 \dot{A}$. Scanning Electron Microscopy (SEM-EDS) untuk meentukan morfologi permukaan bahan yang dikarakterisasi. Alat SEM yang digunakan

\section{Uji Degradasi RBBR}

Aplikasi katalis terbentuk untuk degradasi $R B B R$ dengan cara memasukkan $4 \mathrm{~mL}$ larutan $R B B R 10$ ppm ke dalam labu reaktor. Larutan ditambahkan sejumlah $\mathrm{H}_{2} \mathrm{O}_{2}$ dan katalis ( $\mathrm{Cu}$ bentonit aktivasi dan $\mathrm{Cu}$-bentonit-Au). Reaktor dipanaskan dalam oil bath sambil diaduk selama 84 menit. Larutan hasil degradasi dikarakterisasi menggunakan spektrofotometer UV-Vis.

\section{HASIL DAN PEMBAHASAN}

Hasil karakterisasi struktur kristal dengan menggunakan $X R D$ memperlihatkan tidak terdapat perbedaan signifikan pola difraksi antara bentonit F2 dengan Na-bentonit dapat dilihat di Gambar 1. Tiga sudut difraksi terkuat F2 terletak pada $2 \theta=6,1 ; 20,05$ dan $35,35^{\circ}$. Sementara itu tiga sudut difraksi terkuat $\mathrm{Na}$ bentonit terletak pada $2 \theta=6,45 ; 20,1$ dan $35,75^{\circ}$. Tabel 1 menunjukkan sudut-sudut difraksi pada dua sampel ini.

Hasil XRD ini menunjukkan bahwa penyeragaman kation tidak merusak struktur montmorilonit terlihat dari masih adanya puncak khas milik montmorilonit dan $\mathrm{SiO}_{2}$. Sementara itu pengotor kuarsa masih ada didalam sampel karena kerangka dasar kuarsa adalah $\mathrm{SiO}_{2}$ sehingga sulit hilang dari montmorilonit (Andrini et al. 2017).

Karakterisasi FTIR bentonit F2 diperlihatkan dengan Gambar 2 menunjukkan adanya gugus $\mathrm{Al}-\mathrm{OH}$ pada bilangan gelombang $3621 \mathrm{~cm}^{-1}$. Pada bilangan gelombang $1631 \mathrm{~cm}^{-1}$ adalah vibrasi $\mathrm{O}-\mathrm{H}$ bending, pada $1065 \mathrm{~cm}^{-1}$ adalah pita stretching $\mathrm{Si}-\mathrm{O}-\mathrm{Si}$ yang terdeformasi. adalah SEM JEOL JSM 6510 LA beroperasi pada tegangan $20 \mathrm{kV}$. Spektrometer UV-Vis untuk mengukur energi secara relatif jika energi tersebut ditransmisikan, direfleksikan atau diemisikan sebagai fungsi panjang gelombang. Pada $500-1000 \mathrm{~cm}^{-1}$ terlihat vibrasi Si-O dan Al-O. Sementara karakter Na-bentonit menunjukkan spektra pada bilangan gelombang $3626 \mathrm{~cm}^{-1}$ yang adalah $\mathrm{Si}-\mathrm{OH}$ stretch. Pada bilangan gelombang $1639 \mathrm{~cm}^{-1}$ adalah $\mathrm{O}-\mathrm{H}$ bend, pita stretching Si-O-Si juga terlihat di bilangan gelombang $1090 \mathrm{~cm}^{-1}$. Pada $500-1000 \mathrm{~cm}^{-1}$ terlihat vibrasi Si-O bend dan AlO-Si bend (Alabarse et al. 2011).

Studi morfologi dari Na-bentonit, pilarisasi bentonit dengan $\mathrm{Cu}$ dan immobilisasi naopartikel $\mathrm{Au}$ kedalam bentonit terpilar $\mathrm{Cu}$ diperlihatkan dengan Gambar 3 memperlihatkan, bahwa permukaan Na-bentonit porous dan berongga. Adanya $\mathrm{Cu}$ terpilar didalam antarlapis bentonit belum tampak terlihat jelas pada perbesaran 2000 X. Demikian juga pada pengamatan Cubentonit-Au, nanopartikel Au yang berada di interlayer bentonit juga tidak tampak terlihat. Tabel 2 mentabulasikan studi EDS dari ketiga sampel ini.

Terlihat dengan jelas setelah pilarisasi $\mathrm{Cu}$ kedalam Na-bentonit terjadi peningkatan kandungan $\mathrm{Cu}$ pada interlayer bentonit dari $0,79 \%$ menjadi $18,12 \%$. Hasil ini menyimpulkan bahwa pilarisasi $\mathrm{Cu}$ pada interlayer bentonit berhasil dilakukan. Pilarisasi ini berakibat dari pertukaran ion $\mathrm{Na}^{+}$oleh ion $\mathrm{Cu}^{2+}$, terlihat dari kandungan $\mathrm{Na}$ yang turun menjadi $0,54 \%$ dari 2,07\%. Unsur Au pada Cu-bentonit-Au terdeteksi sebanyak 0,06\%, kecilnya persen massa ini mungkin disebabkan oleh factor sintesis, kestabilan ion logam dalam larutan, kesulitan ion logam yang mengalami aglomerasi dan reaksi yang terjadi antara ion $\mathrm{Au}^{3+}$ dengan montmorilonit dalam interlayer (Chagas et al. 2014).

Tabel 1. Sudut-sudut difraksi F2 dan Na-bentonit

\begin{tabular}{l|l|l|l}
\hline \multicolumn{2}{c}{$\mathbf{2 \theta}$} & Karakterisasi \\
\cline { 1 - 3 } database & Bentonit F2 & Na-bentonit & \\
\hline 16,949 & 6,1 & 6,45 & montmorilonit \\
\hline 19,891 & 20,05 & 20,01 & montmorilonit \\
& 20,95 & 21,15 & SiO2 \\
& 26 & 29,95 & kuarsa \\
& 28,3 & 28,5 & analcime \\
\hline 35,022 & 35,35 & 35,75 & montmorilonit \\
\hline
\end{tabular}




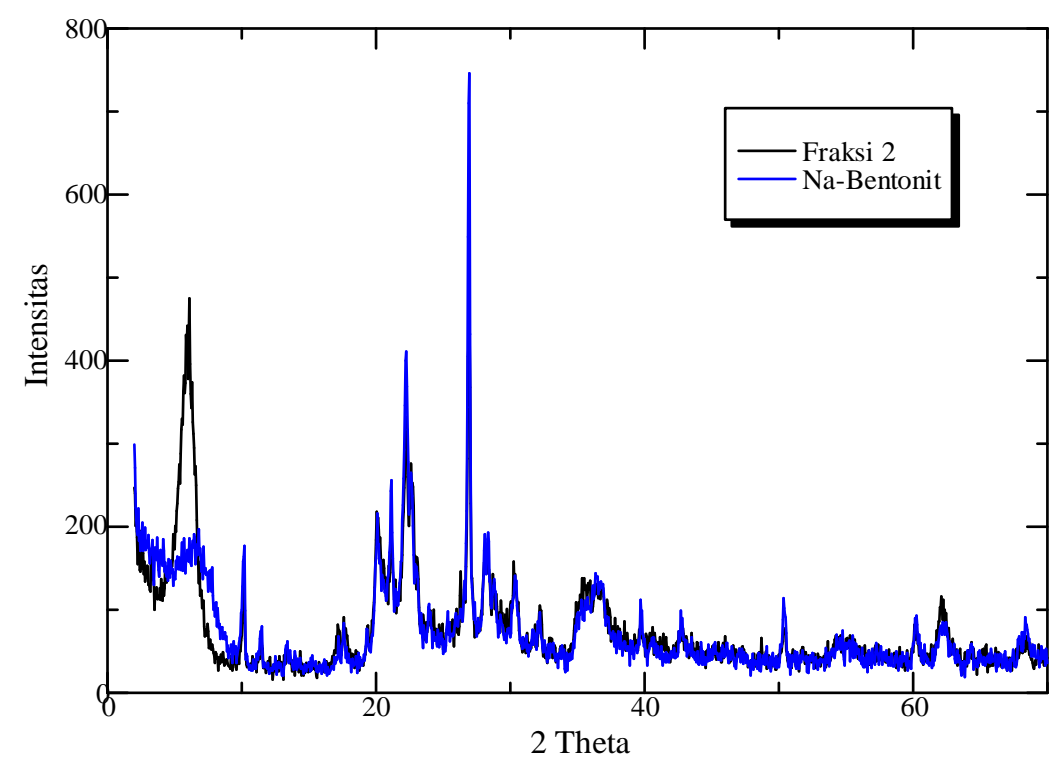

Gambar 1. Pola difraksi bentonit F2 dan Na-bentonit dengan menggunakan XRD

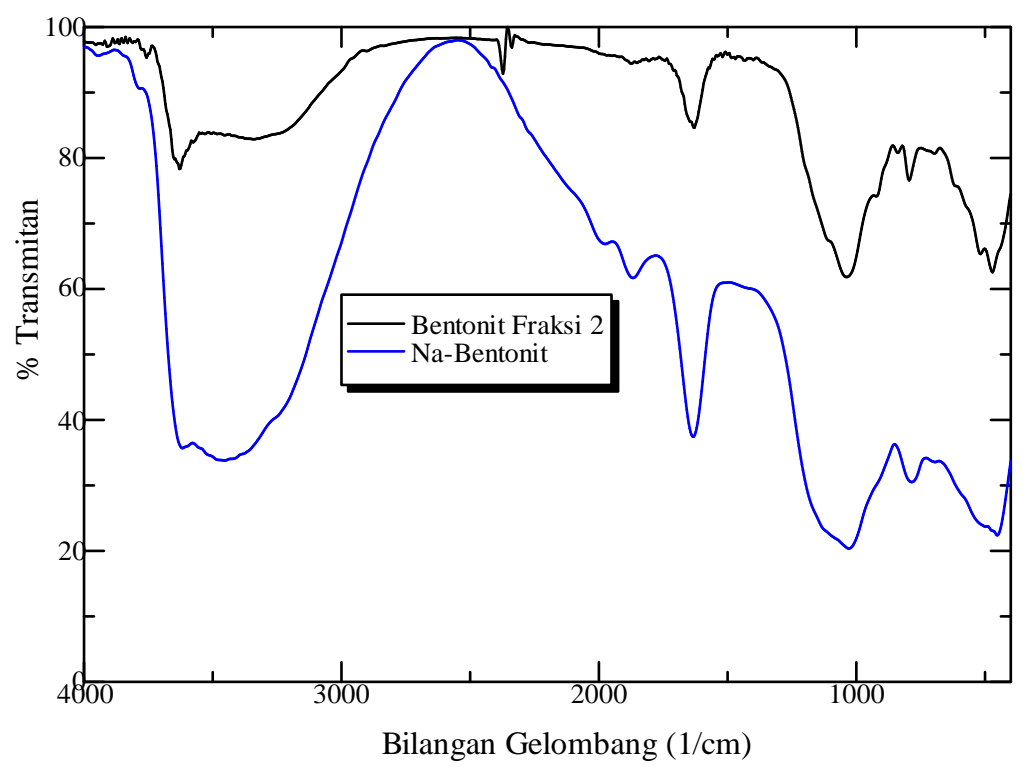

Gambar 2. Spektrum FTIR bentonit F2 dan Na-bentonit. 

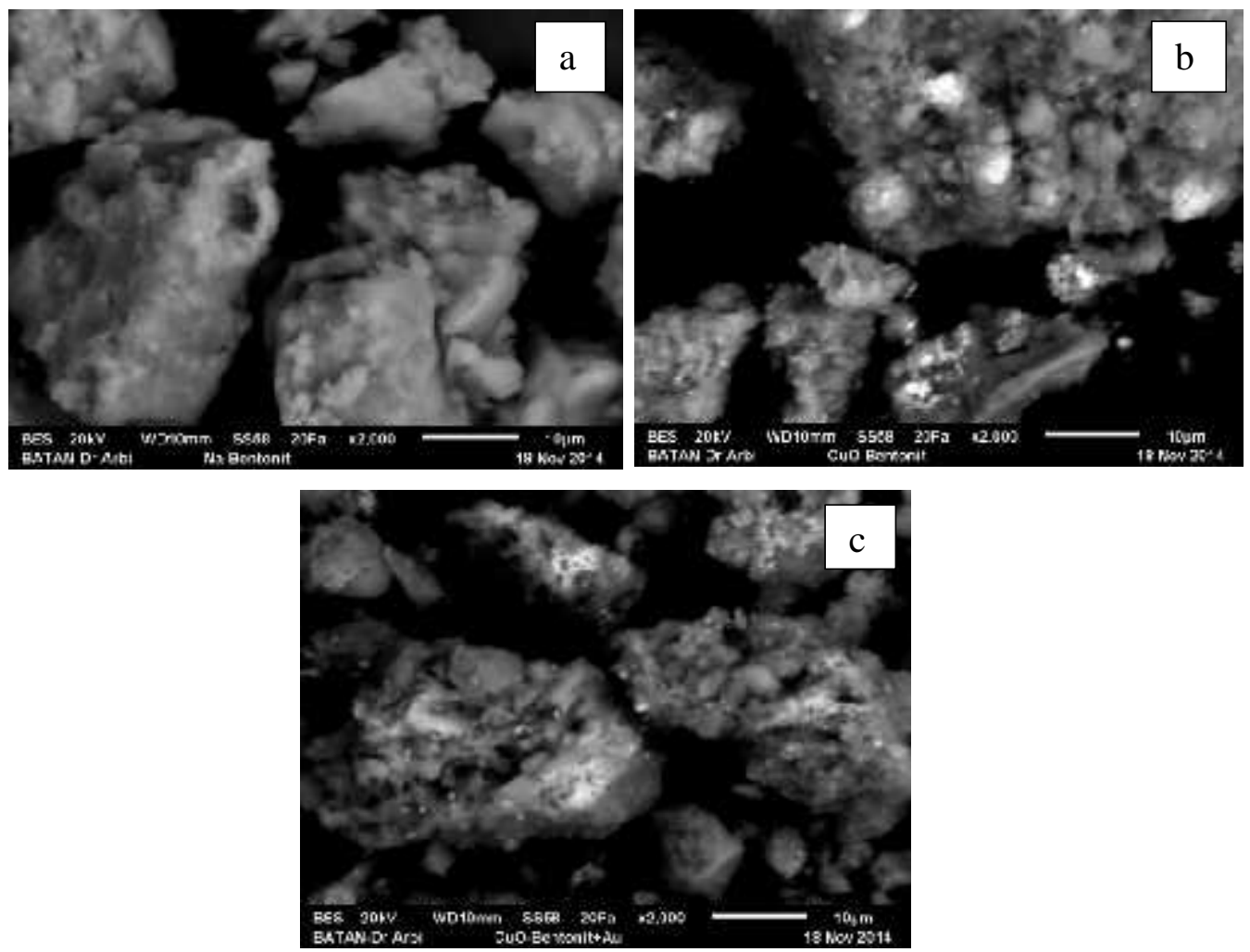

Gambar 3. Morfologi permukaan dari Na-bentonit (a), Cu-bentonit (b) dan Cu-bentonit-Au (c) yang diambil dengan menggunakan SEM pada perbesaran 2000X.

Tabel 2. Studi EDS dari sampel-sampel Na-bentonit, Cu-bentonit dan Cu-bentonit-Au

\begin{tabular}{l|l|l|l}
\hline \multirow{2}{*}{ Unsur } & \multicolumn{3}{|c}{ Sampel (\%) } \\
\cline { 2 - 4 } & Na-bentonit & Cu-bentonit & Cu-bentonit-Au \\
\hline $\mathrm{O}$ & 51,73 & 29,99 & 37,90 \\
\hline $\mathrm{Si}$ & 25,26 & 11,79 & 20,07 \\
\hline $\mathrm{Al}$ & 5,71 & 2,72 & 5,60 \\
\hline $\mathrm{Fe}$ & 1,34 & 2,77 & 1,93 \\
\hline $\mathrm{Ca}$ & 0,27 & 0,3 & 0,20 \\
\hline $\mathrm{K}$ & 0,25 & 0,47 & 0,09 \\
\hline $\mathrm{Mg}$ & 1,33 & 0,52 & 1,40 \\
\hline $\mathrm{Na}$ & 2,07 & 0,54 & 0,90 \\
\hline $\mathrm{C}$ & 10,85 & 22,77 & 8,21 \\
\hline $\mathrm{Cu}$ & 0,79 & 18,12 & 22,13 \\
\hline $\mathrm{Au}$ & 0 & 0 & 0,06 \\
\hline
\end{tabular}




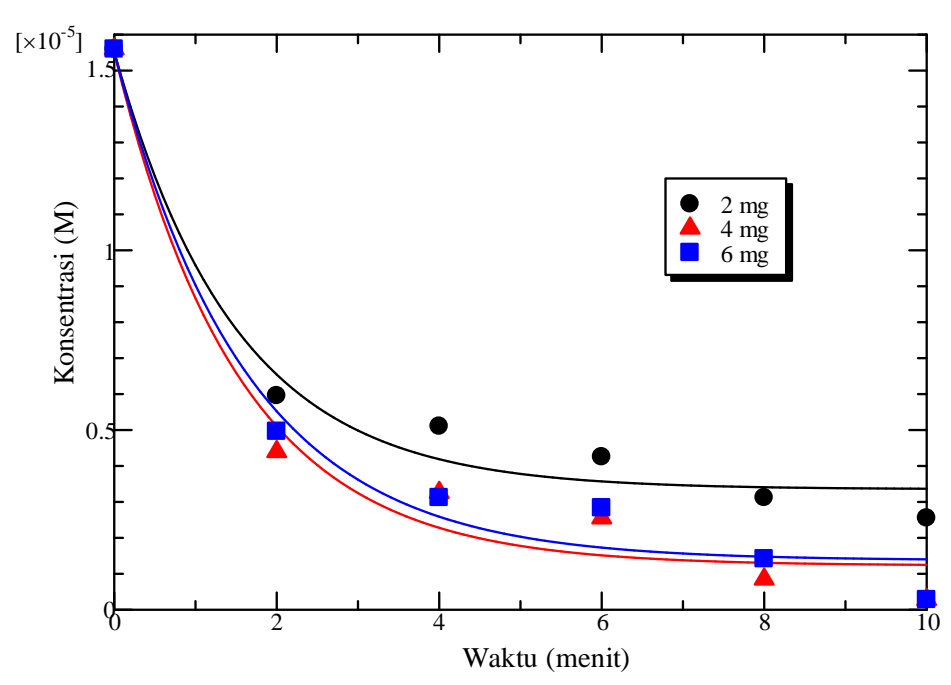

Gambar 4. Kurva penurunan konsentrasi RBBR terhadap waktu reaksi pada jumlah katalis $2,4 \mathrm{mg}$ dan $6 \mathrm{mg}$

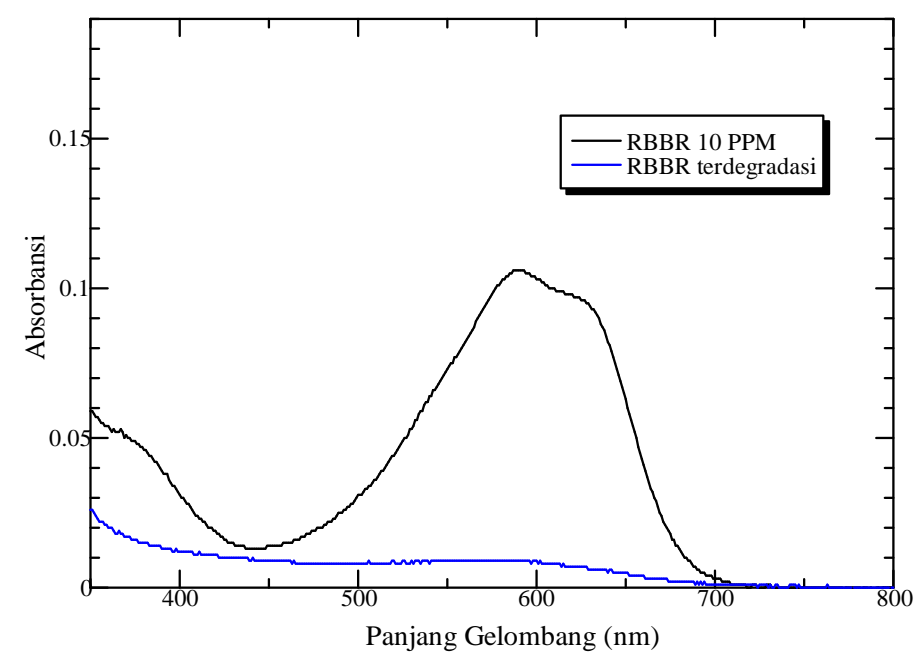

Gambar 5. Spektrum absorpsi UV-Vis RBBR $10 \mathrm{ppm}$ dan degradasi RBBR secara termal tanpa katalis 


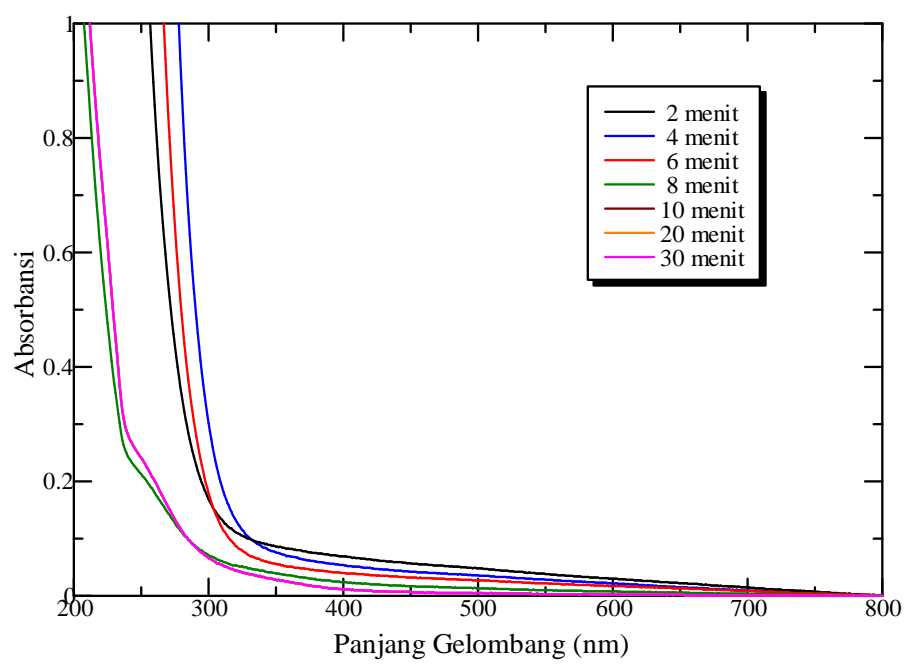

Gambar 6. Spektra absorpsi degradasi $R B B R$ dengan $\mathrm{H}_{2} \mathrm{O}_{2}$ pada jumlah katalis $4 \mathrm{mg}$ terhadap waktu reaksi

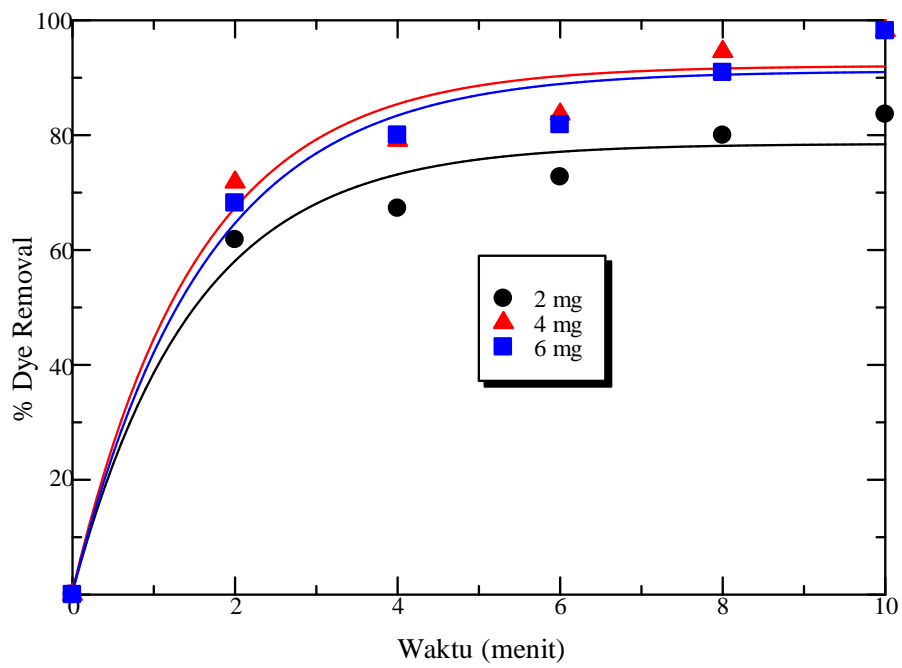

Gambar 7. Persentase dye removal pada jumlah katalis terhadap waktu reaksi.

\section{Studi Cu-bentonit-Au sebagai katalis}

Aktivitas katalitik sangat bergantung pada spesies tembaga di atas katalis Cu-Au-PILC, yang dapat hadir sebagai $\mathrm{Cu}^{2+}, \mathrm{Cu}^{+}$dan $\mathrm{CuO}$. Dan spesies $\mathrm{Cu}^{2+}$ diyakini merupakan situs aktif untuk selective catalytic reduction of NO (SCR NO) di banyak makalah (Guang et al. 2011).

Untuk mengetahui pengaruh jumlah katalis, serangkaian percobaan dilakukan dengan memvariasikan jumlah katalis yaitu 2, 4 dan $6 \mathrm{mg}$. Kurva penurunan konsentrasi $R B B R$ terhadap waktu reaksi pada jumlah katalis ditunjukkan dengan Gambar 4. Bobot katalis optimum diperoleh pada $4 \mathrm{mg}$, yang mampu menurunkan $R B B R$ hingga $98,18 \%$ dalam waktu reaksi 10 menit dibandingkan dengan reaksi tanpa katalis. RBBR semakin banyak yang terdegradasi seiring penambahan berat katalis.
Hal ini dikarenakan situs aktif dari katalis meningkat yang berasal dari semakin bertambahnya luas permukaan, serta nanopartikel $A u$ yang semakin banyak akan mempercepat proses degradasi senyawa $R B B R$ dengan $\mathrm{H}_{2} \mathrm{O}_{2}$.

Pada Gambar 5 terlihat pada $\lambda$ maks 590 $\mathrm{nm}$ terjadi penurunan absorbansi spektrum UVVis $R B B R$ yang menandakan $R B B R$ mengalami degradasi. Penambahan $\mathrm{H}_{2} \mathrm{O}_{2}$ menyebabkan terjadinya degradasi termal RBBR (Grygar et al. 2007). Penambahan $\mathrm{H}_{2} \mathrm{O}_{2}$ akan membentuk radikal hidroksil $(\mathrm{OH})$ yang dipercepat energi termal. Persentasi penghilangan zat warna tanpa katalis adalah $91,82 \%$. Sementara, persentase penghilangan zat warna pada pemuatan katalis ini adalah $98,18 \%$. 
Variasi waktu reaksi pada 2, 4, 6, 8, 10, 20 dan 30 menit dilakukan pada berat katalis optimum $4 \mathrm{mg}$ dengan penambahan $\mathrm{H}_{2} \mathrm{O}_{2}$ dengan suhu reaksi $98{ }^{\circ} \mathrm{C}$ (Gambar 6). Pada masing-masing waktu reaksi diperoleh penurunan nilai absorbansi UV-Vis. Penurunan absorbansi ini menyatakan penurunan konsentrasi $R B B R$ terhadap waktu reaksi. Pada Gambar 6 memperlihatkan bahwa waktu reaksi antara 2-10 menit puncak absorbansi $\lambda_{\text {maks }}$ $(590 \mathrm{~nm})$ semakin menurun dan kemudian konstan pada waktu reaksi 20-30 menit. Hal ini dapat disimpulkan telah terjadi proses degradasi molekul RBBR (Grygar et al. 2007).

Persentase penghilangan zat warna akibat jumlah katalis terhadap waktu reaksi ditunjukkan pada Gambar 7. Titik ekstrim ini dihasilkan dari efek parameter ini pada proses fotokatalitik; pada tingkat jumlah katalis yang lebih rendah, seperti 2 mg, waktu reaksi kira-kira adalah 10 menit dimana peningkatan nyata dalam tingkat penghilangan zat warna (dye removal) terjadi; berbagai zat antara yaitu turunan naftalena dan turunan benzena, yang dihasilkan selama tahap awal, terdegradasi lebih lanjut ke turunan asam di-karboksilat (jenuh atau tidak jenuh), asam karboksilat sederhana seperti asam asetat, asam format, dan akhirnya menjadi $\mathrm{H}_{2} \mathrm{CO}_{3}$ (liq) atau $\mathrm{CO}_{2}$ (gas) (Akyol and Bayramo lu 2005).

\section{KESIMPULAN}

Hasil $X R D$ ini menunjukkan bahwa penyeragaman kation tidak merusak struktur montmorilonit terlihat dari masih adanya puncak khas milik montmorilonit dan $\mathrm{SiO}_{2}$. Pilarisasi $\mathrm{Cu}$ kedalam Na-bentonit berhasil dilakukan terlihat dari terjadi peningkatan kandungan $\mathrm{Cu}$ pada interlayer bentonit dari $0,79 \%$ menjadi $18,12 \%$. Unsur Au pada Cu-bentonit-Au terdeteksi sebanyak 0,06\%, kecilnya persen massa ini mungkin disebabkan oleh faktor sintesis, kestabilan ion logam dalam larutan, kesulitan ion logam yang mengalami aglomerasi dan reaksi yang terjadi antara ion $\mathrm{Au}^{3+}$ dengan montmorilonit dalam interlayer. Uji dengan menggunakan UV-Vis menunjukkan penurunan nilai absorbansi UV-Vis menyatakan penurunan konsentrasi $R B B R$ terhadap waktu reaksi. Bobot katalis optimum diperoleh pada $4 \mathrm{mg}$, yang mampu menurunkan waktu reaksi 10 menit dibandingkan dengan reaksi tanpa katalis. Persentase penghilangan zat warna pada pemuatan katalis ini adalah $98,18 \%$.

\section{DAFTAR PUSTAKA}

Akyol, A., and M. Bayramo lu. 2005. "Photocatalytic Degradation of Remazol Red F3B Using ZnO Catalyst." Journal of
Hazardous Materials 124 (1-3): 241-46. https://doi.org/10.1016/j.jhazmat.2005.05.0 06.

Alabarse, F.G., R.V. Conceição, N.M. Balzaretti, F. Schenato, and A.M. Xavier. 2011. "InSitu FTIR Analyses of Bentonite under High-Pressure." Applied Clay Science 51 $(1-2)$ : 202-8. https://doi.org/10.1016/j.clay.2010.11.017.

Andrini, L., R. Moreira Toja, M. R. Gauna, M. S. Conconi, F. G. Requejo, and N. M. Rendtorff. 2017. "Extended and Local Structural Characterization of a Natural and $800^{\circ} \mathrm{C} \quad$ Fired Na-MontmorillonitePatagonian Bentonite by XRD and $\mathrm{Al} / \mathrm{Si}$ XANES." Applied Clay Science 137: 23340.

https://doi.org/10.1016/j.clay.2016.12.030.

Boylu, F., K. Çinku, F. Esenli, and M.S. Çelik. 2010. "The Separation Efficiency of $\mathrm{Na}$ Bentonite by Hydrocyclone and Characterization of Hydrocyclone Products." International Journal of Mineral Processing 94 (3-4): 196-202. https://doi.org/10.1016/j.minpro.2009.12.00 4.

Caglar, B., O. Cubuk, E. Demir, F. Coldur, M. Catir, C. Topcu, and A. Tabak. 2015. "Characterization of AlFe-Pillared Unye Bentonite: A Study of the Surface Acidity and Catalytic Property." Journal of Molecular Structure 1089 (June): 59-65. https://doi.org/10.1016/j.molstruc.2015.02.0 34.

Chagas, N.V., J.S. Meira, F.J. Anaissi, F.L. Melquiades, S.P. Quináia, M. De Lurdes Felsner, and K.C. Justi. 2014. "Preparation, Characterization of Bentonite Clay/Activated Charcoal Composites and 23 Factorial Design Application in Adsorption Studies of Methylene Blue Dye." Revista Virtual de Quimica 6 (6): 1607-23. https://doi.org/10.5935/19846835.20140104.

Grygar, T., D. Hradil, P. Bezdicka, B. Dousova, L. Capek, and O. Schneeweiss. 2007. "Fe ( III ) - Modified Montmorillonite and Bentonite : Synthesis, Chemical and Uv-Vis Spectral Characterization, Arsenic Sorption, and Catalysis of Oxidative Dehydrogenation of Propane" 55 (2): 16576.

https://doi.org/10.1346/CCMN.2007.05502 06.

Guang, L., L. Xinyong, Q. Zhenping, Z. Qidong, Z. Ling, and C. Guohua. 2011. "Copper-Ion Exchanged Ti-Pillared Clays for Selective Catalytic Reduction of NO by Propylene." Chemical Engineering Journal 168 (3): 1128-33. https://doi.org/10.1016/j.cej.2011.01.095.

Nurdani, Y. 2012. "Sintesis Dan Karakterisasi 
CuO-Bentonit Serta Aplikasinya Sebagai Fotokatalis." Universitas Indonesia.

Quintanilla, A., S. García-Rodríguez, C. M. Domínguez, S. Blasco, J. A. Casas, and J. J. Rodriguez. 2012. "Supported Gold Nanoparticle Catalysts for Wet Peroxide Oxidation." Applied Catalysis B: Environmental 111-112: 81-89. https://doi.org/10.1016/j.apcatb.2011.09.02 0 .

Rastogi, P.K., D.K. Yadav, S. Pandey, V. Ganesan, P.K. Sonkar, and R. Gupta. 2016. "Synthesis and Characterization of Gold Nanoparticles Incorporated Bentonite Clay for Electrocatalytic Sensing of Arsenic(III)." Journal of Chemical Sciences 128 (3): 349-56. https://doi.org/10.1007/s12039-016-1039-7.

Salim, M. 2012. "Preparasi Organoclay Dari Bentonit Merangin - Jambi Dan Surfaktan Nonionik Serta Aplikasinya Sebagai Adsorben p-Klorofenol Dalam Air." Universitas Indonesia.

Sari, A.A., S. Tachibana, and Muryanto. 2012. "Correlation of Ligninolytic Enzymes from the Newly-Found Species Trametes Versicolor U97 with RBBR Decolorization and DDT Degradation." Water, Air, \& Soil Pollution $223 \quad$ (9): $\quad$ 5781-92. https://doi.org/10.1007/s11270-012-1314-2.

Shah, Liaqat Ali, Maria das Graças da Silva Valenzuela, Abdul Mannan Ehsan,
Francisco Rolando Valenzuela Díaz, and Nazir Shah Khattak. 2013. "Characterization of Pakistani Purified Bentonite Suitable for Possible Pharmaceutical Application." Applied Clay Science 83-84: 50-55. https://doi.org/10.1016/j.clay.2013.08.007.

Shah, M.A. 2011. "Preparation of Copper (Cu) and Copper Oxide (Cu2O) Nanoparticles under Supercritical Conditions." Materials Sciences and Applications 02 (08): 97780. https://doi.org/10.4236/msa.2011.28131.

Syuhada, S., R. Wijaya, J. Jayatin, and S. Rohman. 2009. "Modifikasi Bentonit (Clay) Menjadi Organoclay Dengan Penambahan Surfaktan." J. Nano Saintek 2 (1): 48-51.

Xia, Hui-li, Hui-sheng Zhuang, Tao Zhang, and Dong-chang Xiao. 2007. "Photocatalytic Degradation of Acid Blue 62 over CuOSnO2 Nanocomposite Photocatalyst under Simulated Sunlight." Journal of Environmental Sciences 19 (9): 1141-45. https://doi.org/https://doi.org/10.1016/S100 1-0742(07)60186-7.

Zhirong, L., Md.A. Uddin, and S. Zhanxue. 2011. "FT-IR and XRD Analysis of Natural NaBentonite and $\mathrm{Cu}(\mathrm{II})$-Loaded $\mathrm{Na}$ Bentonite." Spectrochimica Acta Part A: Molecular and Biomolecular Spectroscopy 79 (5): 1013-16. https://doi.org/10.1016/j.saa.2011.04.013. 